\title{
Micro- and fine-scale distribution of microplankton in the feeding environment of larval flounder
}

\author{
Greg P. Jenkins* \\ Department of Zoology, University of Melbourne, Parkville, Victoria 3052, Australia
}

\begin{abstract}
Micro- to fine-scale distribution of microplankton, collected concurrently with larval flounders Rhombosolea tapirina and Ammotretis rostratus in the Werribee region of Port Phillip Bay, Australia, on 11, 17, 22 July and 16 August 1984, was investigated. Three replicate $4 \mathrm{l}$ samples were collected with a submersible water pump at $1,3,5$, and $7 \mathrm{~m}$ depths, at each of 2 stations $50 \mathrm{~m}$ apart. The micro-scale distribution of the majority of taxa amongst $4 \mathrm{l}$ replicates was random. The principle exception was invertebrate eggs, which were highly aggregated on 2 of 4 dates. Two-factor analysis of variance revealed considerable fine-scale heterogeneity in microplankton distribution. Most variability occurred in the vertical plane, but significant heterogeneity in fine-scale horizontal distribution was also evident for some taxa. Fine-scale patchiness tended to be multispecific, with positive correlation between the distributions of many taxa, including important prey of flounder larvae such as bivalve veligers. A few taxa, particularly Acartia tranteri nauplii, were negatively correlated with other taxa on some dates. The maximum individual abundance in a single replicate was 2 to 3 times greater than the overall mean abundance, estimated by pooling samples, for most taxa. Although fine-scale patchiness of important prey for larval flounder was evident, abundances of microplankton were well below levels often thought necessary for significant survival of larval fish.
\end{abstract}

\section{INTRODUCTION}

Inadequate food is considered to be a major source of mortality in larval fish, leading to direct starvation or reducing larval growth rate and therefore increasing exposure to size-selective predation (Shepherd \& Cushing 1980, Smith 1985). The abundance of prey necessary for significant larval survival in the laboratory is often greater than 1000 microzooplankters $1^{-1}$, which is considerably higher than the average usually observed in the sea (Hunter 1981). This observation has led to the 'patchiness' hypothesis, which contends that larval survival is dependent on high concentrations of prey occurring at smaller scales than can be discriminated by most plankton sampling methods.

Some earlier studies may have been unduly pessimistic, however, because significant survival and growth of larval fish have recently been obtained at

\footnotetext{
- Present address: Division of Fisheries Research, CSIRO Marine Laboratories, GPO Box 1538, Hobart, Tasmania 7001, Australia
}

prey abundances similar to those observed in the sea (Houde 1978, Øiestad 1982, Kiorboe \& Munk 1986). Nevertheless, food consumption and growth rate of marine fish larvae have a positive functional relationship with prey abundances within the range observed in the sea (Houde 1978, Houde \& Schekter 1980, 1981). Since slow growth may be more important than direct starvation in larval mortality (Hunter 1981), patchiness of prey at these lower abundance levels could be critical.

Marine fish larvae have an ambit on the order of 100 to $1000 \mathrm{~m} \mathrm{~d}^{-1}$, and have effective search volumes on the order of 0.1 to $10 \mathrm{l}^{-1} \mathrm{~h}^{-1}$ depending on size (Houde \& Alpern Lovdal 1985). Therefore the appropriate spatial scales to investigate patchiness in prey are micro$(1 \mathrm{~cm}$ to $1 \mathrm{~m})$ to fine-scale (metres to 100's of metres) (Haury et al. 1978). Horizontal fine-scale patchiness of phytoplankton (Cassie 1959) and macrozooplankton (Cassie 1963, Fasham 1978, Haury et al. 1978) is well documented; however heterogeneity is particularly pronounced in the vertical dimension (Longhurst 1981). Although fine-scale patchiness of macrozooplankton has been well studied, microzooplankton, which typi- 
cally dominate the diets of larval fish, have received much less attention. The fine-scale distribution of microzooplankters consumed by larval fish was found to be heterogeneous in Long Island Sound (Peterson \& Asubel 1984), the St. Lawrence estuary (Fortier \& Leggett 1984), the Southern California Bight (Mullin et al. 1985), and the North Sea (Ellertsen et al. 1981). In contrast, Houde \& Alpern Lovdal (1985) found little fine-scale aggregation in total copepod nauplii in Biscayne Bay, Florida, USA. Plankton patchiness has also been demonstrated on a micro-scale for phytoplankton (Cassie 1959, Owen 1981) and microzooplankton (Owen 1981).

Larvae of the flounders Rhombosoled tapirina and Ammotretis rostratus collected from the Werribee region of Port Phillip Bay, Australia, in 1984 were selective feeders (Jenkins 1987a), and had higher growth rates than the same species reared in the laboratory in conditions of high food abundance (Jenkins 1987b). The objective of the present study is to investigate the micro- and fine-scale distribution of microplankton which co-occurred with larval flounders, and attempt to relate prey microdistribution and abundance to previous results on feeding and growth of flounder larvae.

\section{METHODS}

Study area. Port Phillip bay, Australia, is a large $\left(1950 \mathrm{~km}^{2}\right.$ ) embayment with a narrow entrance and a water residence time of $\sim 180 \mathrm{~d}$. Tidal currents within the bay are weak and water column stratification is rare (Anonymous 1973, Kimmerer \& McKinnon 1985). Sampling was conducted in the northern region of Port Phillip Bay (Fig. 1) in winter 1984. The Werribee zone (sensu Jenkins 1986) was chosen as the general study area because high abundances of larval flounder, determined by exploratory plankton tows over the study period, occurred in this area. The area is characterised by high nutrient and chlorophyll levels relative to the rest of the bay (Anon 1973).

Field sampling. Significant numbers of flounder larvae occurred on 11, 17, 22 July and 16 August 1984 (Jenkins 1987a). Specific sampling sites were selected by making trial plankton tows until significant numbers of larval flounder were located (Fig. 1). Once larval flounder were located, the water parcel was tracked with a parachute drogue deployed at $5 \mathrm{~m}$ depth. Water sampling to investigate microplankton distribution was immediately preceeded by a vertical profile of temperature-salinity using a Beckman RS5-3 field salinometer.

The aim of the water sampling was to quantify microand fine-scale distribution of microplankton over a period short enough to minimize the effect of temporal

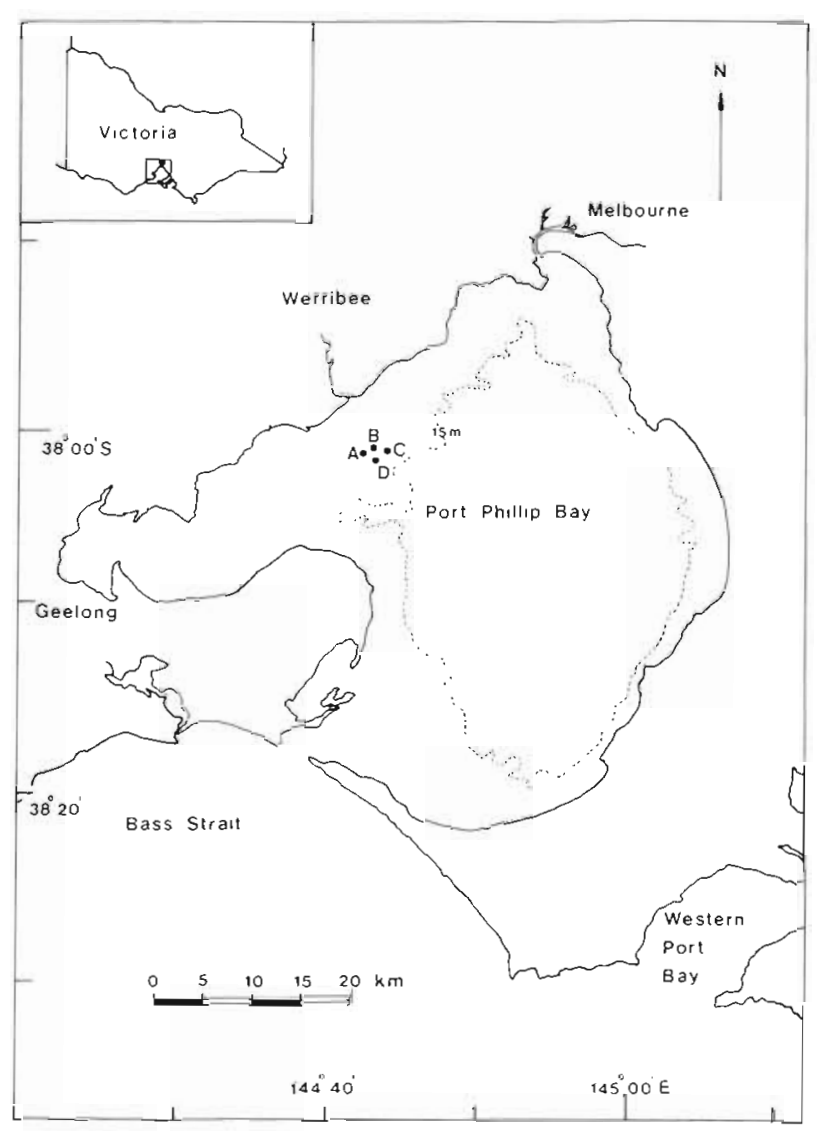

Fig. 1. Port Phillip Bay, Victoria, Australia, showing sampling locations: (A) 11 Jul 1984 (depth $=8 \mathrm{~m}$ ), (B) 17 Jul 1984 (depth $=8 \mathrm{~m})$, (C) $22 \mathrm{Jul} 1984$ (depth $=9 \mathrm{~m})$, (D) 16 Aug 1984 (depth $=9 \mathrm{~m}$ )

variability on spatial distribution. Water samples for microplankton analysis were collected at 2 stations, Stns 1 and 2,50 $\mathrm{m}$ apart (measured by buoy and line attached to the drogue) at depths of 1, 3, 5, and $7 \mathrm{~m}$ (water depth 8 to $9 \mathrm{~m}$ ). A submersible pump and $5 \mathrm{~cm}$ i. d. hose (flow rate $85 \mathrm{l} \mathrm{min}^{-1}$ ) was used to fill 3 replicate 4 I sample jars with water from each depth. Samples of $4 \mathrm{l}$ were chosen after a pilot study indicated that this sample size would provide sufficient organisms for analysis, and at the same time would be small enough to allow for total counts, therefore eliminating the extra variability introduced by subsampling. Exact sample volumes were determined from graduations on jars. Drogue movement relative to the anchored boat was $<1 \mathrm{~m}$ while samples were collected at each station. After all samples were collected (total sampling time was $<5 \mathrm{~min}$ ), each was filtered through a $35 \mu \mathrm{m}$ mesh and retained microplankton was preserved in $2 \%(\mathrm{v} / \mathrm{v})$ formalin in seawater. In the laboratory, all zooplankton and some phytoplankton taxa were counted. Immediately following microplankton sampling, 4 consecutive macroplankton samples were taken around the drogue 
at ca 4 to $5 \mathrm{~m}$ depth to collect larval flounder (Jenkins 1987a).

Data analysis. To investigate departure from randomness in organism abundance in the 3 replicates collected at sampling points (a sampling point represents one depth at one station), $\chi^{2}=$ variance/mean was calculated for all sampling points with replicate mean $>5$. The $\chi^{2}$ values were then summed over depths and stations to get a total $\chi^{2}$ for each sampling date which was tested for aggregation $(p<0.05)$ and regularity $(p>0.95)$ (George 1974). Species which had mean $<5$ for more than 4 sampling points were excluded from analyses. Calculations involved raw sample counts only (Cassie 1963).

Departure from randomness in replicates was also investigated using Lloyd's (1967) patchiness index. This index is the ratio of 'mean crowding', $\bar{X}+\left[\left(\mathrm{S}^{2} / \overline{\mathrm{X}}\right)-1\right]$ ( $\mathrm{S}^{2}=$ variance), to the mean density $\overline{\mathrm{X}}$. The degree of 'patchiness' is defined as the proportion by which the mean crowding exceeds the mean density. The main advantage of this index is that it is unaffected by sample size or organism abundance (George 1974, Houde \& Alpern Lovdal 1985). Using the same criteria as in the $\chi^{2}$ analysis, the patchiness index was calculated for sampling points, summed over depths and stations, and divided by the number of sampling points analysed to get an average patchiness index.

Variation in abundance among depths and stations was analysed by 2 -factor analysis of variance, with depth and station treated as fixed factors (Underwood 1981). Abundances were standardised to numbers per litre. Only taxa which occurred in $>80 \%$ of samples (i.e. 20 or more samples) were analysed. Heterogeneity among variances was examined using Cochran's test (Winer 1971). Where necessary, data were $\log _{10}(X+1)$ transformed in an attempt to homogenise variances. Species for which this procedure was unsuccessful were excluded from analyses. When a significant interactive effect occurred between abundances at depths and stations, the significance of main effects was not tested, as individual hypotheses about variation in abundance with depth and station were then too broad to provide useful information (Underwood 1981). The null hypothesis was rejected at the 0.05 level of significance.

Correlation among distributions of taxa was examined using principle components analysis (Dixon 1975). Abundances were $\log _{10}(X+1)$ transformed for analysis (Cassie 1963). After initial extraction, components were subjected to orthogonal (Varimax) rotation in an attempt to obtain simple structure.

\section{RESULTS}

With the exception of slight surface warming on 11 July and a slight salinity increase near the bottom on 16 August, the water column was well mixed on all 4 sampling dates (Fig. 2). The sampling period included the minima of the annual temperature cycle in Port Phillip Bay (Jenkins 1986). Sea conditions on these dates were calm to slight (wind speed 0 to $5 \mathrm{~m}$ $\mathrm{s}^{-1}$ ).

The majority of species on all dates were randomly distributed in sets of replicates (Table 1). Bivalve veligers were aggregated on 11 July, and regularly distributed on 22 July. Pleurosigma were aggregated on both dates on which their distributions were analysed. Invertebrate eggs were aggregated on 22 July and 16 August. Oithona nauplii were regularly distributed
Fig. 2. Depth profiles of temperature (solid line) and salinity (dashed line) on 4 sampling dates

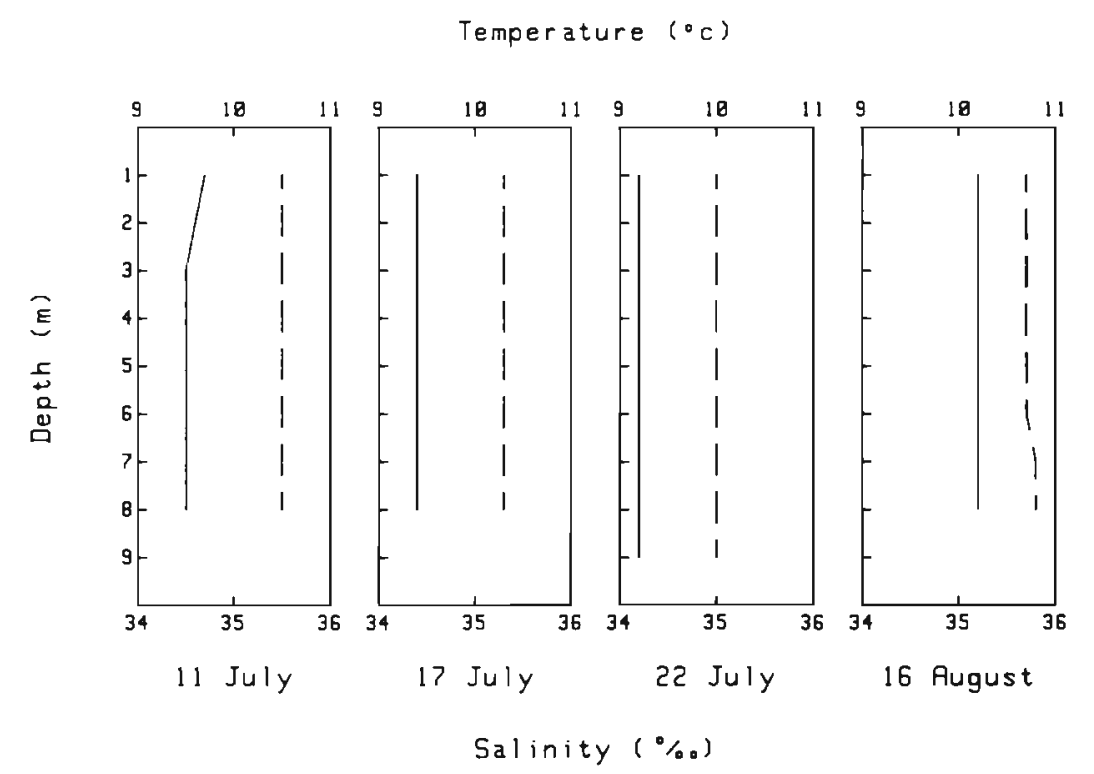


Table 1 . Sum of the $x^{2}=$ variance/mean values, and mean of Lloyd's patchiness index, for sampling points with a replicate mean $>$ 5. Analysis was not conducted if less than 4 sampling points had a replicate mean $>5$

\begin{tabular}{|c|c|c|c|c|c|c|c|c|c|c|c|c|}
\hline \multirow[b]{2}{*}{ Taxon } & \multicolumn{3}{|c|}{11 July } & \multicolumn{3}{|c|}{17 July } & \multicolumn{3}{|c|}{22 July } & \multicolumn{3}{|c|}{16 August } \\
\hline & $\begin{array}{c}n \\
\text { total }\end{array}$ & $\begin{array}{c}\chi^{2} \\
\text { total }\end{array}$ & $\begin{array}{l}\text { Mean } \\
\text { Lloyd's } \\
\text { patchi- } \\
\text { ness }\end{array}$ & $\begin{array}{c}n \\
\text { total }\end{array}$ & $\begin{array}{c}\chi^{2} \\
\text { total }\end{array}$ & $\begin{array}{l}\text { Mean } \\
\text { Lloyd's } \\
\text { patchi- } \\
\text { ness }\end{array}$ & $\begin{array}{c}n \\
\text { total }\end{array}$ & $\begin{array}{c}x^{2} \\
\text { total }\end{array}$ & $\begin{array}{l}\text { Mean } \\
\text { Lloyd's } \\
\text { patchi- } \\
\text { ness }\end{array}$ & $\begin{array}{c}n \\
\text { total }\end{array}$ & $\begin{array}{c}x^{2} \\
\text { total }\end{array}$ & $\begin{array}{l}\text { Mean } \\
\text { Lloyd's } \\
\text { patchi- } \\
\text { ness }\end{array}$ \\
\hline \multicolumn{13}{|l|}{ Diatoms } \\
\hline Coscinodiscus & 24 & 17.14 & 1.04 & 24 & 14.84 & 1.05 & 24 & 26.06 & 1.03 & 24 & 25.89 & 1.02 \\
\hline Pleurosigma & 21 & $24.20^{\circ}$ & 1.26 & & & & & & & 24 & $56.84^{*}$ & 1.07 \\
\hline \multicolumn{13}{|l|}{ Dinoflagellates } \\
\hline Protoperidinium & & & & & & & & & & 18 & 15.67 & 1.08 \\
\hline \multicolumn{13}{|l|}{ Tintinnids } \\
\hline Tintinnopsis & & & & & & & 24 & 16.25 & 1.02 & 24 & 20.93 & 1.04 \\
\hline Favella & & & & & & & & & & 24 & 12.10 & 1.06 \\
\hline \multicolumn{13}{|l|}{ Rotifers } \\
\hline Synchaeta & 18 & 7.25 & 1.02 & & & & 24 & 17.73 & 1.13 & 24 & 15.72 & 1.06 \\
\hline \multicolumn{13}{|l|}{ Cladocerans } \\
\hline Evadne nordmanni & & & & & & & 12 & 5.90 & 1.08 & & & \\
\hline \multicolumn{13}{|l|}{ Copepod nauplii } \\
\hline Oithona & 21 & $6.24^{\mp}$ & 0.99 & 15 & $3.81^{t}$ & 0.98 & 24 & 14.77 & 1.12 & 24 & $7.77^{\star}$ & 1.00 \\
\hline Acartia tranteri & 21 & 7.26 & 0.98 & 15 & 11.24 & 1.14 & 18 & 8.61 & 1.03 & 24 & 8.32 & 1.00 \\
\hline Paracalanids & & & & & & & 21 & 12.37 & 1.05 & 24 & 14.79 & 1.06 \\
\hline Harpacticoids & & & & & & & & & & 24 & 14.46 & 1.03 \\
\hline Total & 24 & 17.22 & 1.04 & 24 & 20.60 & 1.14 & 24 & 13.62 & 1.03 & 24 & 14.62 & 1.00 \\
\hline \multicolumn{13}{|l|}{ Copepodids and adults } \\
\hline Oithona & & & & & & & & & & 18 & 8.24 & 1.03 \\
\hline Euterpina acutifrons & & & & & & & & & & 18 & 8.60 & 1.02 \\
\hline Paracalanus indicus & & & & 12 & 2.82 & 0.95 & & & & & & \\
\hline Total & 18 & 8.27 & 1.06 & 24 & 13.59 & 1.07 & 12 & 8.20 & 1.15 & 24 & 21.18 & 1.10 \\
\hline Invertebrate eggs & 24 & 19.39 & 1.09 & 24 & 9.63 & 1.00 & 24 & $71.52^{\circ}$ & 1.19 & 24 & $252.35^{*}$ & 1.36 \\
\hline Bivalve veligers & 24 & $55.03^{\circ}$ & 1.18 & 24 & 13.97 & 0.98 & 24 & $6.99^{+}$ & 1.00 & 24 & 15.62 & 1.02 \\
\hline Total microzooplankton & 24 & $42.26^{\circ}$ & 1.03 & 24 & 16.99 & 1.02 & 24 & $26.91^{\circ}$ & 1.01 & 24 & $62.56^{\circ}$ & 1.02 \\
\hline
\end{tabular}

among replicates on 3 of the 4 sampling dates. Mean values of Lloyd's patchiness index for replicates tended slightly towards aggregation for most taxa; however only invertebrate eggs on 16 August showed a major departure from random expectation. Patchiness in this case was mainly attributable to replicates from $7 \mathrm{~m}$ at Stn 1 and $1 \mathrm{~m}$ from Stn 2, where abundances between replicates varied by a factor of almost 10 (approximately 7 to $68 \mathrm{l}^{-1}$ ). Other replicates, however, showed much less variation.

Significantly different abundances among sampling points occurred in 8 of 11 indivictual taxa analysed on 11 July, 5 of 6 taxa on 17 July, 8 of 12 taxa on 22 July, and 12 of 19 taxa on 16 August (Table 2). Most variability occurred over depth; however significant interactions were also common, particularly on 11 July. The fine-scale distribution of bivalve veligers was highly variable on all dates. The distribution of larvaceans on 16 August was unusual in that a significant difference in abundance occurred between sta- tions but not amongst depths. Abundance of pooled taxa was also variable on a fine-scale; the distributions of developmental stages of copepods were heterogeneous on 11 July and 16 August, fine-scale distribution of total microzooplankton was heterogeneous on all dates.

Table 3 compares the overall mean abundance of common microplankton taxa, calculated by dividing the total number of each taxon in the 24 samples by the total volume of water sampled, with the maximum abundance in an individual 41 sample. In general, the maximum abundance differs from the mean abundance by a factor of approximately 2 to 3 . This difference tends to be greatest for species which show significant fine-scale heterogeneity. The major exception to this was the 4-to 5-fold difference between the maximum abundance and the mean for invertebrate eggs on 22 July and 16 August, which was related to high replicate variability (Table 1 ).

Similarities in distribution of many microplankton 
Table 2. F-ratios for depth, station, and interaction terms of a 2-factor analysis of variance of microplankton distributions

\begin{tabular}{|c|c|c|c|c|c|c|c|c|c|c|c|c|}
\hline \multirow{2}{*}{ Taxon } & \multirow{2}{*}{ Depth } & \multicolumn{2}{|l|}{11 July } & \multicolumn{3}{|c|}{$17 \mathrm{July}$} & \multicolumn{3}{|c|}{22 July } & \multicolumn{3}{|c|}{16 August } \\
\hline & & Station & $D \times S$ & Depth & Station & $\mathrm{D} \times \mathrm{S}$ & Depth & Station & $\mathrm{D} \times \mathrm{S}$ & Depth & Station & $D \times S$ \\
\hline \multicolumn{13}{|l|}{ Diatoms } \\
\hline Coscinodiscus & & & & $6.05^{\circ}$ & 1.09 & 1.98 & $19.55^{\cdots}$ & 1.99 & 0.52 & $4.56^{\circ}$ & $11.23^{\circ}$ & 2.02 \\
\hline Pleurosigma & 1.88 & 0.66 & 0.45 & & & & 1.05 & 0.06 & 0.35 & 2.46 & 2.76 & 2.23 \\
\hline \multicolumn{13}{|l|}{ Dinoflagellates } \\
\hline Protoperidinium & & & & & & & & & & 12.91 & 4.91 & $3.71^{\circ}$ \\
\hline \multicolumn{13}{|l|}{ Tintinnids } \\
\hline Tintinnopsissp. 1 & & & & & & & 13.00 & 2.18 & $10.14^{\cdots}$ & $3.27^{\circ}$ & 1.65 & 0.41 \\
\hline Tintinnopsis sp. 2 & & & & & & & & & & 1.12 & 1.06 & 2.70 \\
\hline \multicolumn{13}{|l|}{ Scyphomedusae } \\
\hline $\begin{array}{l}\text { Cyanea capillata } \\
\text { planulae }\end{array}$ & $5.45^{\circ}$ & 0.08 & 2.31 & & & & $32.64 " \cdot$ & 0.05 & 1.29 & & & \\
\hline \multicolumn{13}{|l|}{ Rotifers } \\
\hline Trichocerca & & & & & & & & & & $4.69^{\circ}$ & 0.13 & 2.63 \\
\hline Synchaeta & 1.52 & 3.00 & 1.29 & & & & 2.69 & 3.00 & 1.42 & 0.61 & 2.32 & 2.16 \\
\hline $\begin{array}{l}\text { Polychaete } \\
\text { trochophores }\end{array}$ & & & & & & & $3.70^{\circ}$ & 0.13 & 2.54 & 0.68 & 1.52 & 0.16 \\
\hline \multicolumn{13}{|l|}{ Cladocerans } \\
\hline Evadne nordmanni & & & & & & & $12.52 \cdots$ & 3.45 & 0.90 & & & \\
\hline \multicolumn{13}{|l|}{ Copepod nauplij } \\
\hline Oithona & & & & 11.31 & 0.00 & $3.81^{\circ}$ & 0.29 & 0.82 & 0.15 & 0.73 & 0.14 & 0.12 \\
\hline Acartia tranteri & 1.20 & 3.42 & $7.86^{\circ}$ & $4.83^{\circ}$ & 0.64 & 1.97 & 3.04 & 2.29 & 0.20 & 2.21 & 2.45 & 2.60 \\
\hline Paracalanid & 16.73 & 0.04 & $3.91^{\circ}$ & & & & $9.25^{\circ}$ & 0.68 & 0.29 & 10.10 & 7.20 & $3.86^{\circ}$ \\
\hline Harpacticoid & & & & & & & & & & 3.83 & 0.44 & 2.70 \\
\hline Total & 25.05 & 7.19 & $10.26^{\cdots}$ & 1.45 & 3.16 & 1.66 & 2.94 & 0.50 & 0.19 & 2.77 & 0.01 & 3.15 \\
\hline \multicolumn{13}{|l|}{ Copepodid and adults } \\
\hline Oithona & & & & & & & & & & $5.85^{\circ}$ & 0.18 & 1.26 \\
\hline Acartia tranteri & & & & & & & & & & $11.83^{\circ} \cdot$ & • 2.06 & 2.11 \\
\hline Paracalanus indicus & 7.12 & 0.00 & $6.01^{\circ}$ & $16.03^{\cdots}$ & $5.51^{\circ}$ & 2.41 & $11.20^{\cdots}$ & 3.58 & 2.63 & 8.51 & 9.60 & $7.98^{\circ}$ \\
\hline Euterpina acutifrons & & & & & & & & & & $10.12^{\cdots}$ & - 2.22 & 1.90 \\
\hline Total & 13.11 & 0.43 & $12.24^{\cdots}$ & 2.31 & 0.13 & 0.58 & & & & $11.38^{\circ}$ & 1.77 & 2.41 \\
\hline Invertebrate eggs & 2.58 & 0.09 & 0.81 & 2.05 & 2.34 & 1.90 & & & & 1.08 & 0.00 & 1.11 \\
\hline Bivalve veligers & 42.86 & 25.54 & $11.33^{\cdots}$ & 57.22 & 17.71 & $10.39^{\cdots}$ & 89.29 & 44.04 & $5.31^{\circ}$ & 52.14 & 12.38 & $14.99^{\circ}$ \\
\hline \multicolumn{13}{|l|}{ Larvaceans } \\
\hline Oikopleura dioica & & & & & & & & & & 2.49 & $4.80^{\circ}$ & 1.34 \\
\hline Total microzooplankton & 54.75 & 17.59 & $10.46^{\cdots}$ & 68.56 & 31.78 & $9.04^{\circ}$ & $11.35^{\circ}$ & 2.19 & 0.49 & 3.14 & 1.89 & $4.65^{\circ}$ \\
\hline${ }^{\cdot} p<0.05 ; \cdots p<0.001$ & & & & & & & & & & & & \\
\hline
\end{tabular}

taxa in space (Fig. 3 to 6) and a higher frequency of significant correlations between taxa on each date than would be expected by chance (binomial test, $p<0.001$ ) indicated that principle components analysis would be the correct procedure to reduce the data set to interpretable results (Colebrook 1977, Reid et al. 1978). The correlation matrix on each date could be reduced to a few components which explained a significant proportion of the variance in the data. Examination of component loadings for individual taxa indicates that the component explaining the highest proportion of the variance on each date was related to positive correlation between some taxa (Table 4). With the exception of the second most important factor on 17 July, lower order factors were less interpretable and are not included in this analysis.
The most important component on 11 July (45\% of variance) related to positive correlation between developmental stages of paracalanid copepods, bivalve veligers, Oithona nauplii and Coscinodiscus. On 17 July, 2 components each explained approximatey $40 \%$ of the variance in the data set. The first related to positive correlation between abundances of invertebrate eggs, Oithona nauplii, Paracalanus indicus copepodid/adults and bivalve veligers. The second component related to the strong negative correlation between Acartia tranteri nauplii and all other taxa except invertebrate eggs. The most important component for 22 July ( $34 \%$ of variance) related to positive correlation among a suite of taxa again including bivalve veligers, Coscinodiscus and paracalanid nauplii; and also related to negative correlation between 
Table 3. Pooled replicate abundance and maximum replicate abundance of common microplankton taxa

\begin{tabular}{|c|c|c|c|c|c|c|c|c|}
\hline \multirow[b]{2}{*}{ Taxon } & \multicolumn{2}{|c|}{11 July } & \multicolumn{2}{|c|}{17 July } & \multicolumn{2}{|c|}{22 July } & \multicolumn{2}{|c|}{16 August } \\
\hline & $\begin{array}{c}\text { Pooled } \\
\text { replicate } \\
\text { abundance } \\
\left(\text { no. } 1^{-1}\right)\end{array}$ & $\begin{array}{l}\text { Maximum } \\
\text { replicate } \\
\text { abundance } \\
\text { (no. } 1^{-1} \text { ) }\end{array}$ & $\begin{array}{c}\text { Pooled } \\
\text { replicate } \\
\text { abundance } \\
\left(\text { no. } 1^{-1}\right)\end{array}$ & $\begin{array}{l}\text { Maximum } \\
\text { replicate } \\
\text { abundance } \\
\text { (no. } 1^{-1} \text { ) }\end{array}$ & $\begin{array}{l}\text { Pooled } \\
\text { replicate } \\
\text { abundance } \\
\left(\text { no. } 1^{-1}\right)\end{array}$ & $\begin{array}{l}\text { Maximum } \\
\text { replicate } \\
\text { abundance } \\
\left(\text { no. } l^{-1}\right)\end{array}$ & $\begin{array}{l}\text { Pooled } \\
\text { replicate } \\
\text { abundance } \\
\left(\text { no. } 1^{-1}\right)\end{array}$ & $\begin{array}{l}\text { Maximum } \\
\text { replicate } \\
\text { abundance } \\
\left(\text { no. } 1^{-1}\right)\end{array}$ \\
\hline \multicolumn{9}{|l|}{ Diatoms } \\
\hline Coscinodiscus & 8.18 & 15.61 & 4.14 & 8.95 & 16.61 & 33.75 & 25.15 & 37.62 \\
\hline Pleurosigma & 2.26 & 5.26 & & & 0.67 & 2.25 & 23.61 & 44.25 \\
\hline \multicolumn{9}{|l|}{ Dinoflagellate } \\
\hline \multicolumn{9}{|l|}{ Tintinnids } \\
\hline Tintinnopsis sp. 1 & & & & & 15.20 & 28.05 & 10.36 & 15.79 \\
\hline Tintinnopsis sp. 2 & & & & & & & 0.63 & 1.5 \\
\hline Favella & & & & & & & 3.70 & 6.82 \\
\hline \multicolumn{9}{|l|}{ Scyphomedusae } \\
\hline $\begin{array}{l}\text { Cyanea capillata } \\
\text { planulae }\end{array}$ & 0.98 & 3.41 & & & 0.76 & 2.25 & & \\
\hline \multicolumn{9}{|l|}{ Rotifers } \\
\hline Trichocerca & & & & & & & 0.75 & 1.90 \\
\hline Synchaeta & 1.37 & 3.33 & & & 2.58 & 8.16 & 3.93 & 7.14 \\
\hline $\begin{array}{l}\text { Polychaete } \\
\text { trochophores }\end{array}$ & & & & & 0.83 & 5.61 & 0.51 & 1.18 \\
\hline \multicolumn{9}{|l|}{ Cladocerans } \\
\hline Evadne nordmanni & & & & & 1.68 & 4.36 & & \\
\hline \multicolumn{9}{|l|}{ Copepod nauplij } \\
\hline Oithona & 2.58 & 5.50 & 1.53 & 3.42 & 1.89 & 3.50 & 4.52 & 5.75 \\
\hline Acartia tranteri & 2.49 & 6.10 & 1.30 & 4.15 & 1.76 & 4.50 & 8.79 & 14.28 \\
\hline Paracalanids & 2.40 & 6.51 & & & 2.54 & 7.14 & 4.20 & 11.25 \\
\hline Harpacticoids & & & & & & & 8.44 & 14.25 \\
\hline Total & 7.93 & 17.07 & 4.05 & 7.37 & 6.49 & 9.52 & 26.61 & 37.50 \\
\hline \multicolumn{9}{|l|}{ Copepodids and adults } \\
\hline Oithona & & & & & & & 1.98 & 4.00 \\
\hline Acartia tranteri & & & & & & & 0.88 & 2.25 \\
\hline Paracalanus indicus & 1.10 & 3.72 & 1.09 & 2.82 & 0.60 & 1.84 & 1.33 & 4.50 \\
\hline Euterpina acutifrons & & & & & & & 2.29 & 5.00 \\
\hline Total & 2.06 & 6.05 & 2.18 & 4.00 & 1.24 & 4.47 & 6.57 & 13.00 \\
\hline Invertebrate eggs & 3.55 & 8.00 & 3.47 & 6.84 & 6.89 & 26.0 & 11.87 & 56.75 \\
\hline Bivalve veligers & 17.32 & 49.25 & 14.64 & 27.57 & 21.68 & 36.67 & 18.79 & 34.29 \\
\hline \multicolumn{9}{|l|}{ Larvaceans } \\
\hline Oikopleura dioica & & & & & & & 1.10 & 2.25 \\
\hline Total microzooplankton & 35.81 & 76.5 & 27.77 & 47.63 & 59.36 & 77.95 & 86.24 & 122.5 \\
\hline
\end{tabular}

this group of taxa and Paracalanus indicus copepodid/ adults. The most important component on 16 August explained a lower proportion of the variance in the data than previous dates $(23 \%)$. This component again related to a multi-species association including bivalve veligers, developmental stages of paracalanid copepods and Coscinodiscus, and, as for 17 July, also related to negative correlation between $A$. tranteri nauplii and this group. The inclusion of other taxa because of higher abundances than on previous dates, many of which had independent distributions, reduced the total variability in the data set explained by the correlated taxa.

\section{DISCUSSION}

Micro-scale patchiness of microplankton would have been of little importance to feeding of flounder larvae at the time of sampling. Flounder larvae selected against invertebrate eggs and rarely ate the diatom Pleurosigma (Jenkins 1987a). The pronounced aggregation of invertebrate eggs was probably caused by highly localized egg release. The aggregation of Pleurosigma at this scale could have related to association with aggregates of material providing physical substrate, analogous to the association between pennate diatoms and 'marine snow' reported by Silver 

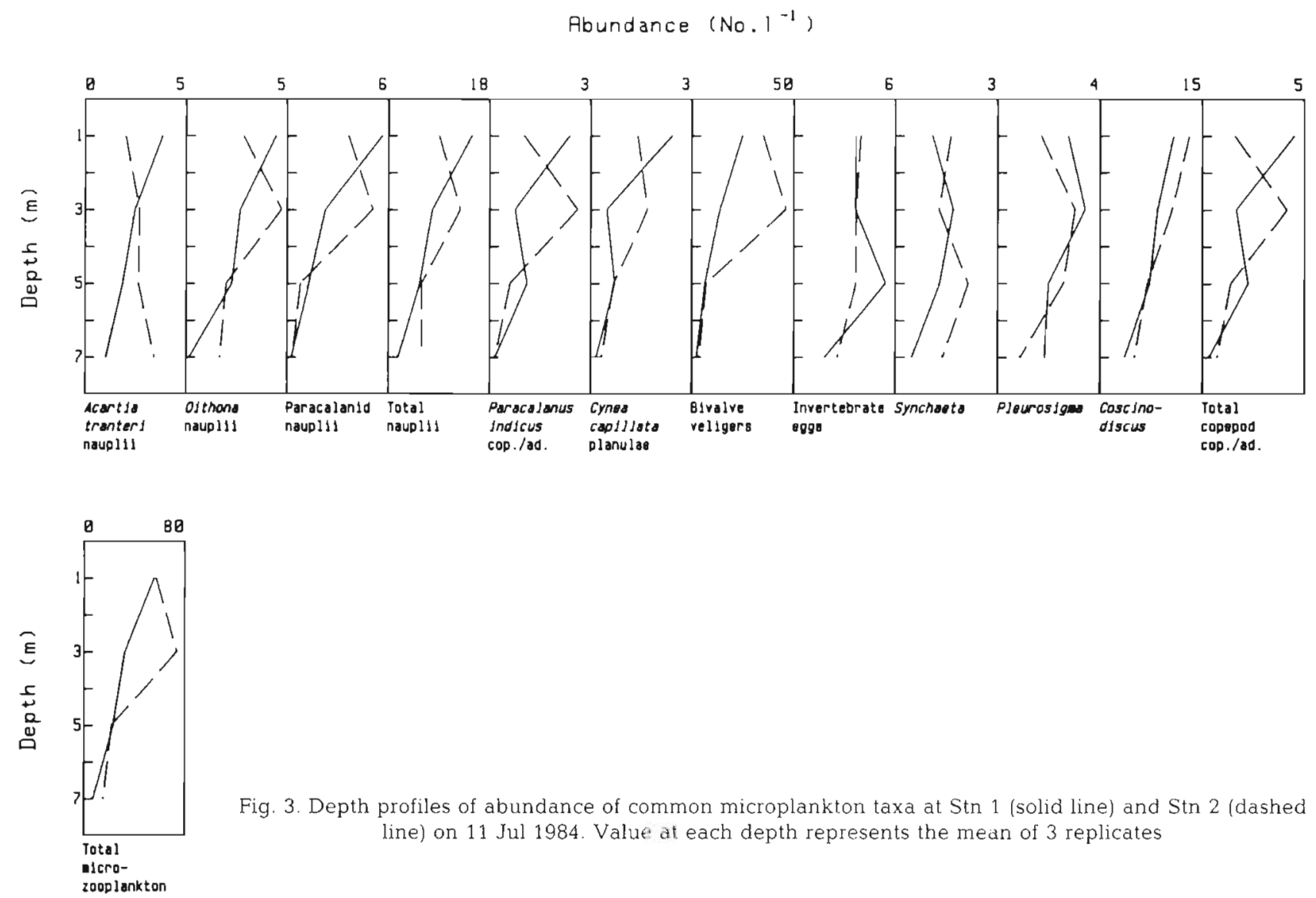

Fig. 3. Depth profiles of abundance of common microplankton taxa at Stn 1 (solid line) and Stn 2 (dashed line) on 11 Jul 1984 . Value at each depth represents the mean of 3 replicates

2000] ankton

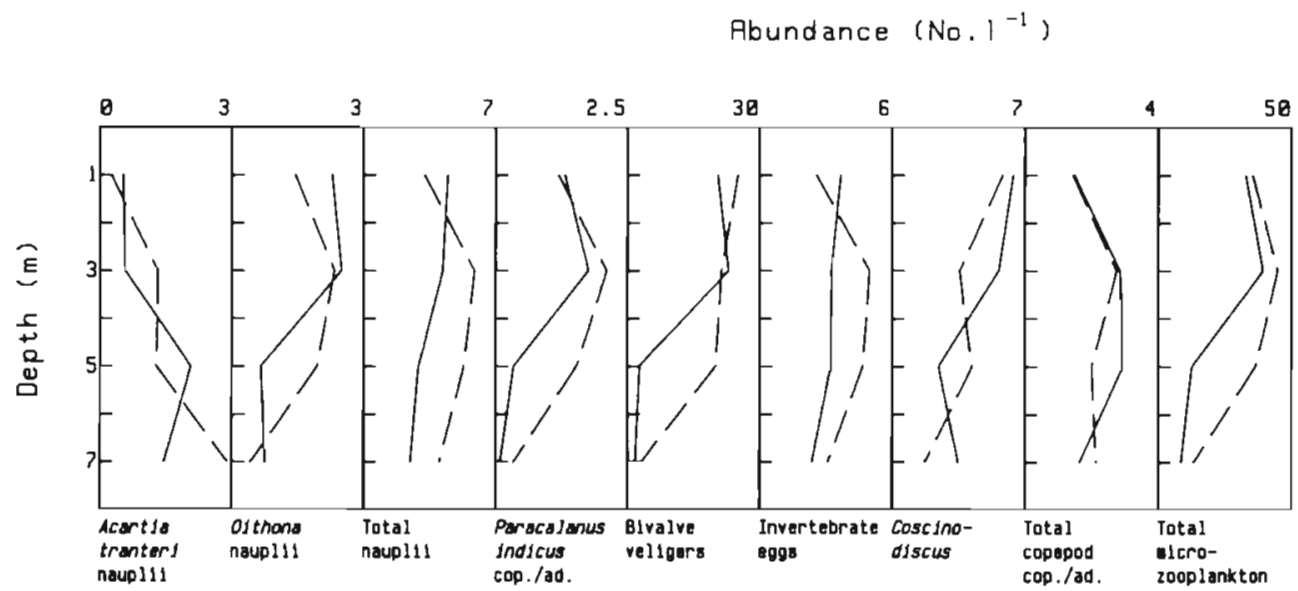

Fig. 4. Depth profiles of abundance of common microplankton taxa at Stn 1 (solid line) and Stn 2 (dashed line) on 17 Jul 1984 Value at each depth represents the mean of 3 replicates

et al. (1978). Some heterogeneity in distribution at this scale may have been disrupted by turbulence at the pump opening (Haury et al. 1978).

The random distribution of most microplankton on a micro-scale allowed a test of departure from randomness in distribution on a fine-scale. Significant vertical and/or horizontal patchiness in fine-scale distribution was observed for a large number of taxa. The greatest variation occurred on the vertical scale, which is a typical result when vertical and horizontal variability is compared simultaneously (Fielder 1983). Thus, flounder larvae would have encountered greater variation in prey abundance by moving a few metres vertically than by moving tens of metres horizontally. However, 


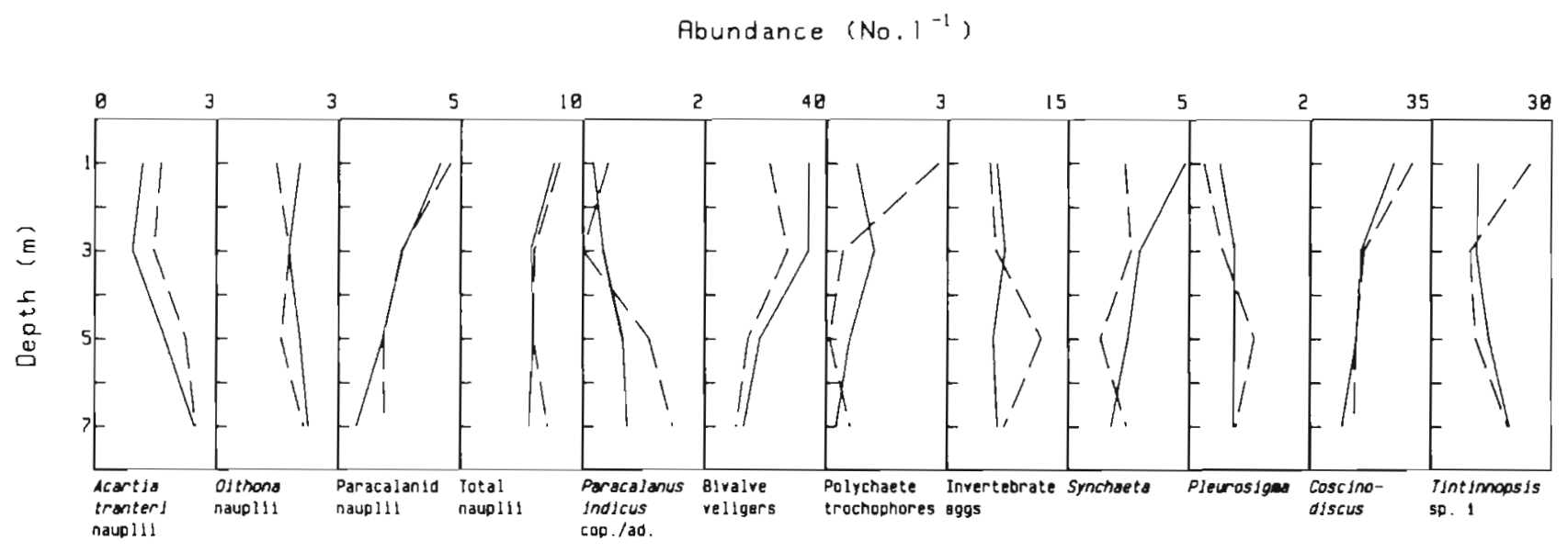

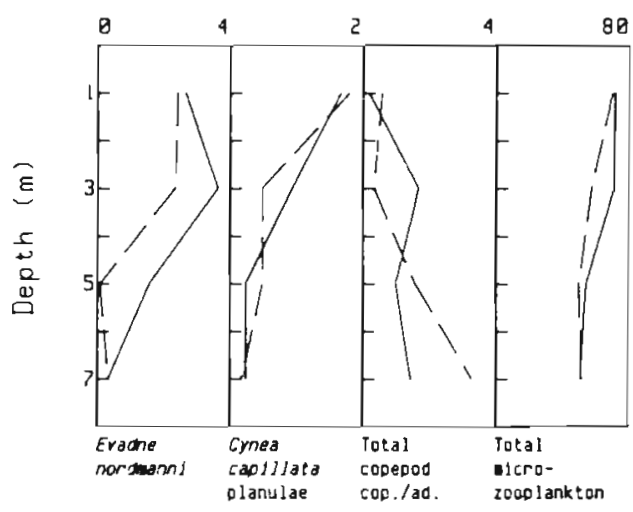

significant differences between sampling stations and significant interactions between station and depth were common. Therefore flounder larvae moving in a horizontal plane would encounter variable abundance of a number of prey taxa.

Concordance in abundance of certain taxa indicated that some groups were responding to similar environmental factors, or that distribution patterns were the result of biological interactions (Haury \& Wiebe 1982). It is possible that some of the observed horizontal variability was due to the imposition of physical disturbance on a group of taxa with similar depth preferences. The lack of stratification in the water column would negate the effect of internal waves on plankton distribution (Fasham 1978, Haury et al. 1979). However, Langmuir cells could have interacted with microplankton movement to produce horizontal and vertical heterogeneity (Stavn 1971, George \& Edwards 1973). A further possible mechanism for multi-species patchiness is the effect of grazing by schools of planktivorous fish moving through the area (Greenblatt 1982, Fulton 1985), however abundance of these fish in Port Phillip Bay is likely to be low over winter months (Blackburn 1950a, b).

The multi-species patches included a number of taxa which were selectively eaten by larval flounders, such as bivalve veligers, Evadne nordmanni, and developmental stages of paracalanid copepods (Jenkins 1987a). Although the distributions of most taxa were positively correlated, in some cases, such as Acartia tranteri nauplii on 17 July and 16 August, strong negative correlation with the majoriy of taxa occurred, suggesting an opposite response to the factor(s) inducing aggregation. If flounder aggregate in multi-species patches (Hunter \& Thomas 1974), the distribution of $A$. tranteri could provide an explanation for selection against this prey taxon (Jenkins 1987a). These multispecies patterns are not necessarily consistent in time Paracalanus indicus copepodids/adults were usually positively associated with multi-species patches, but, on 22 July, they were negatively associated. This pattern probably relates to differences in depth distribution between dates. For example, older copepod stages may vary their vertical position in response to factors such as tidal currents to maintain horizontal position (Wooldridge \& Erasmus 1980).

The 'patchiness' hypothesis is not supported by the results of this study. Abundances of microzooplankton recorded at micro- to fine-scales were well below those typically used for rearing larvae of marine fish (Hunter 

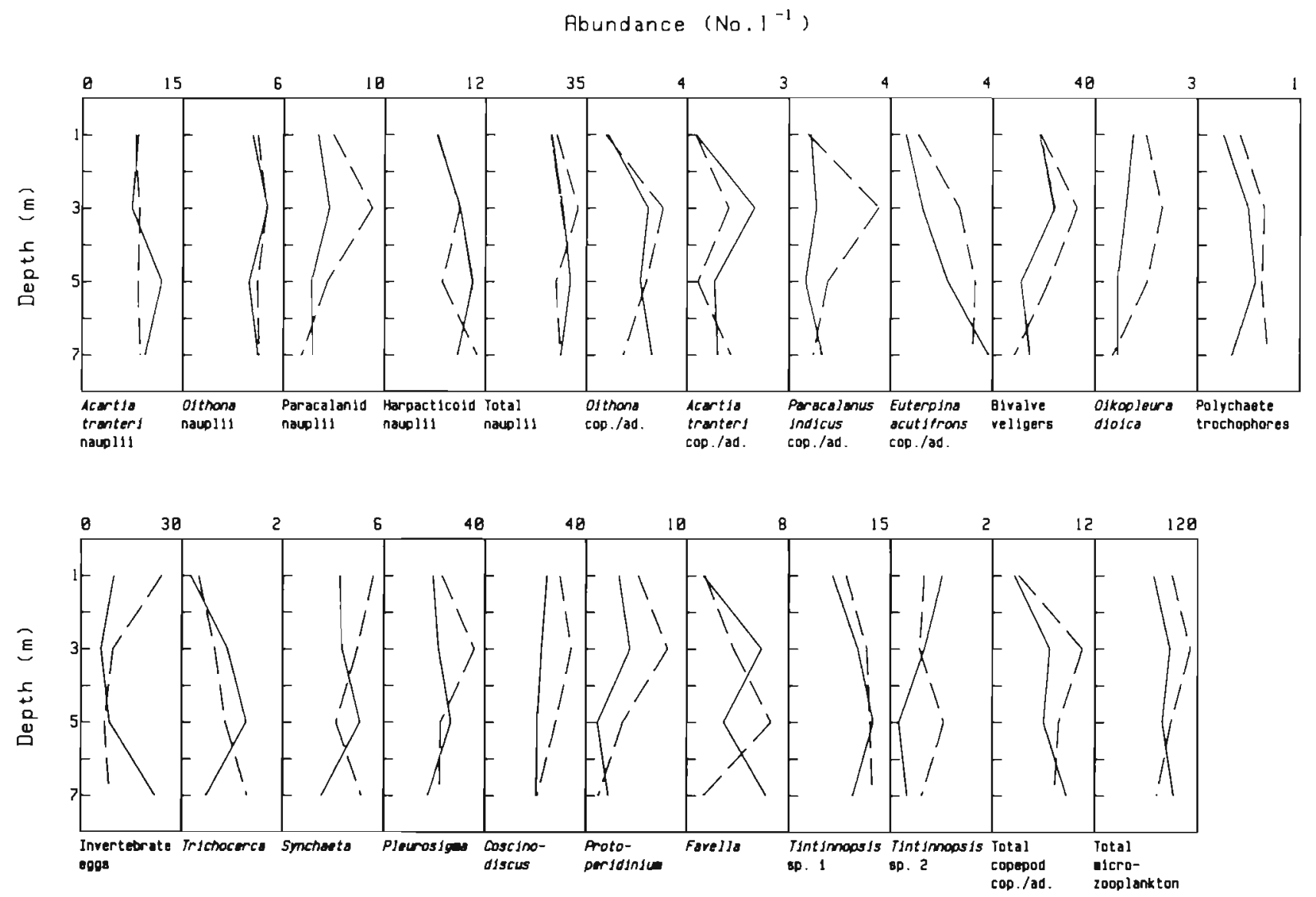

Fig. 6. Depth profiles of abundance of common microplankton taxa at Stn 1 (solid line) and Stn 2 (dashed line) on 16 Aug 1984 . Value at each depth represents the mean of 3 replicates

1981). However, growth of flounder larvae collected concurrently with microplankton over the study period was comparable to that recorded in the laboratory with an order of magnitude higher food abundance (Jenkins 1987b). The contention that feeding conditions were generally good for flounder larvae was supported by the very high incidence of feeding and the rejection of some prey types in favour of preferred taxa (Jenkins $1987 \mathrm{a}$ ). These results support the conclusion of Kiørboe \& Munk (1986) and Øiestad (1982) that most laboratory rearing procedures overestimate the abundance of prey necessary for larval survival.

It is possible that vertical migration could have led to greater abundances of zooplankton in the surface layers at dusk than was recorded in the water column at the time of sampling (around midday). However, this argument may only reasonably apply to older stages of copepods and other larger zooplankton. In general, younger stages of vertically migrating copepods do not undergo significant migrations (Williams \& Conway 1980, Fancett \& Kimmerer 1985, Bayly 1986), although Ellertsen et al. (1981) found some evidence for vertical migration in late-stage nauplii of Calanus finmarchicus. The vertical migratory behaviour of other microzooplankton has received little study. Investigation of diurnal variation in the number of prey consumed by flounder larvae in this study (Jenkins 1987a) indicates that feeding rate was relatively constant, other than a slight reduction in the early morning. A feeding peak at, or after sunset, which may have been expected if vertical migration was important in concentrating prey organisms, was not detected. Nevertheless, the vertical migratory behaviour of larval flounder and their microzooplankton prey warrants further investigation.

Abundances of microplankton recorded in this study were within the range used in experiments by Houde (1978) to obtain significant ( $>10 \%$ ) larval survival. The 2- to 3-fold difference between overall mean abundance (equivalent to an integrating plankton tow) and the maximum replicate abundance may significantly affect larval survival, as growth rates are an increasing function of prey concentration at prey levels similar to those observed in this study (Wyatt 1972, Houde \& Schekter 1981). Thus growth rate and survival may be 


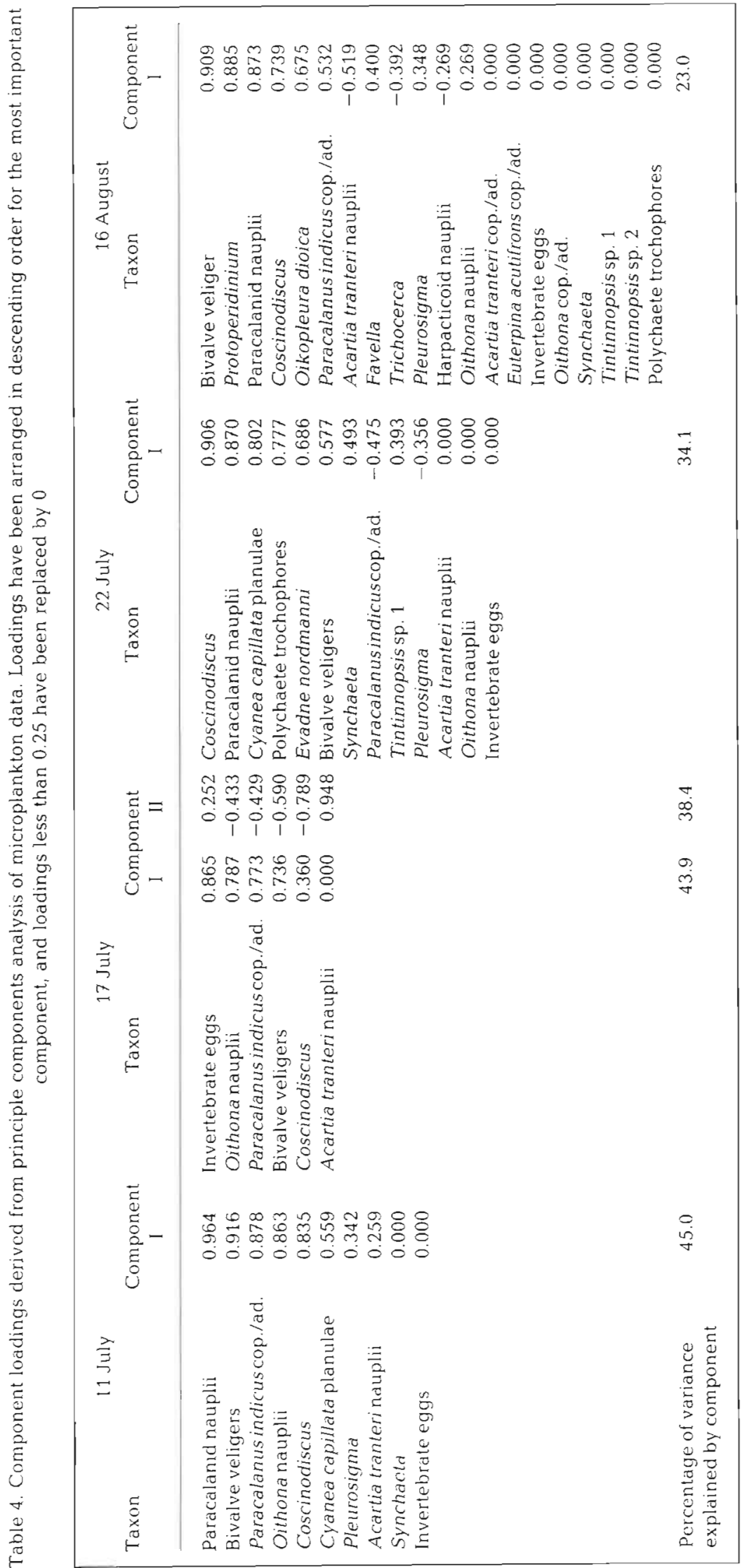


significantly higher than would be predicted from average concentrations determined from a typical vertical or oblique net tow.

Acknowledgements. I am especially grateful to Dr W Kimmerer for useful discussions and advice throughout this study. I thank M. Fancett, J. Jenkins and T Ross-Smith for assistance with field work. D. McKinnon, K. Ough and D. Hill kindly helped with plankton identifications. I also thank Drs W. Kimmerer, G. Watson, G. Arnott, J. Leis and I. Bayly for commenting on drafts of this manuscript. This work was undertaken as part of the requirements for a Ph. D. degree at the University of Melbourne.

\section{LITERATURE CITED}

Anonymous (1973). Environmental study of Port Phillip Bay Report on Phase One, 1968-1971. Melbourne and Metropolitan Board of Works, and Fisheries and Wildlife Department of Victoria, Melbourne

Bayly, I. A. E. (1986). Aspects of diel vertical migration in zooplankton, and its enigma variations. In: De Deckker, P., Williams, W. D. (eds.) Limnology in Australia. CSIRO Aust, Melbourne. W. J. Junk, Dordrecht, p. 349-368

Blackburn, M. (1950a). A biological study of the anchovy, Engraulis australis (White), in Australian waters. Aust. J. mar Freshwat. Res. 1: 3-84

Blackburn, M. (1950b). Studies on the age, growth, and life history of the Australian pilchard, Sardinops neopilchardus (Steindachner), in southern and western Australia. Aust. J. mar. Freshwat. Res. 1: 221-258

Cassie, R. M. (1959). Micro-distribution of plankton. N.Z. Jl Sci. 2: 398-409

Cassie, R. M. (1963). Microdistribution of plankton. Oceanogr mar Biol. Ann. Rev. 1. 223-252

Colebrook, J. M. (1977). Annual fluctuations in biomass of taxonomic groups in the California Current, 1958-59. Fish. Bull. U. S. 75: 357-368

Dixon, W J. (ed.) (1975). BMDP biomedical computer programs. University of California Press, Berkeley

Ellertson, B., Moksness, E., Solemdal, P., Tilseth, S., Westgard, T, Øiestad, V (1981). Feeding and vertical distribution of cod larvae in relation to availability of prey organisms. Rapp. P.-v. Réun. Cons. int. Explor. Mer 178: 317-319

Fancett, M. S., Kimmerer, W J. (1985). Vertical migration of the demersal copepod Pseudodiaptomus as a means of predator avoidance. J. exp. mar. Biol. Ecol. 88: 31-43

Fasham, M. J. R. (1978). The statistical and mathematical analysis of plankton patchiness. Oceanogr. mar. Biol. Ann. Rev. 16: $43-79$

Fiedler, P. C. (1983). Fine-scale spatial patterns in the coastal epiplankton off southern California. J. Plankton Res. 5: 865-879

Fortier, L., Leggett, W. C. (1984). Small-scale covariability in the abundance of fish larvae and their prey. Can. J. Fish. Aquat. Sci. 41: 502-512

Fulton, R. S. III. (1985). Predator-prey relationships in an estuarine littoral copepod community. Ecology 66: 21-29

George, D. G. (1974). Dispersion patterns in the zooplankton populations of a eutrophic reservoir. J. Anim. Ecol. 43: $537-551$

George, D. G., Edwards, R. W. (1973). Daphnia distribution ith Langmuir circulations. Limnol. Oceanogr. 18: 798-800

Greenblatt, P. R. (1982). Small-scale horizontal distributions of zooplankton taxa. Mar Biol. 67: 97-111
Haury, L. R., McGowan, J. A., Wiebe, P. H. (1978). Patterns and processes in the time-space scales of plankton distributions. In: Steele, J. H. (ed.) Spatial pattern in plankton communities. Plenum Press, New York, p. 277-327

Haury, L. R., Briscoe, M. G., Orr, M. H. (1979). Tidally generated internal wave packets in Massachusetts Bay. Nature, Lond. 278: $312-317$

Haury, L. R., Wiebe, P. H. (1982). Fine-scale multi-species aggregations of oceanic zooplankton. Deep Sea Res. 29: 915-921

Houde, E. D. (1978). Critical food concentrations for larvae of three species of subtropical marine fishes. Bull. mar. Sci. 28: 395-411

Houde, E. D., Alpern Lovdal, J. (1985). Patterns of variability in ichthyoplankton occurrence and abundance in Biscayne Bay, Florida. Estuar. coast. Shelf Sci. 20: 79-103

Houde, E. D., Schekter, R. C. (1980). Feeding by marine fish larvae: developmental and functional responses. Env. Biol. Fish. 5: 315-334

Houde, E. D., Schekter, R. C. (1981). Growth rates, rations and cohort consumption of marine fish larvae in relation to prey concentrations. Rapp. P.-v. Réun. Cons. int. Explor Mer 178: $441-453$

Hunter, J. R. (1981). Feeding ecology and predation of marine fish larvae. In: Lasker, R. (ed.) Marine fish larvae. Morphology, ecology and relation to fisheries. Washington Sea Grant Programm, Seattle and London, p. 34-77

Hunter, J. R., Thomas, G. L. (1974). Effect of prey distribution and density on the searching and feeding behaviour of larval anchovy Engraulis mordax Girard. In: Blaxter, J. H. S. (ed.) The early life history of fish. Springer-Verlag, Berlin, p. 559-574

Jenkins, G. P. (1986). Composition, seasonality and distribution of ichthyoplankton in Port Phillip Bay, Victoria. Aust. J. mar. Freshwat. Res. 37: 507-520

Jenkins, G. P. (1987a). Comparative diets, prey selection and predatory impact of co-occurring larvae of two flounder species. J. exp. mar. Biol. Ecol. 110: 147-170

Jenkins, G. P. (1987b). Age and growth of co-occurring larvae of two flounder species, Rhombosolea tapirina and Ammotretis rostratus. Mar. Biol. 95: 157-166

Kimmerer, W. J., McKinnon, A. D. (1985). A comparative study of the zooplankton in two adjacent embayments, Port Phillip and Westernport Bays, Australia. Estuar. coast. Shelf Sci. 21: 145-159

Kiorboe, T., Munk, P. (1986). Feeding and growth of larval herring, Clupea harengus, in relation to density of copepod nauplii. Env. Biol. Fish. 17. 133-139

Lloyd, L. (1967). Mean crowding. J. Anim. Ecol. 36: 1-30

Longhurst, A. R. (1981). Significance of spatial variability. In: Longhurst, A. R. (ed.) Analysis of marine ecosystems. Academic Press, London, p. 415-441

Mullin, M. M., Brooks, E. R., Reid, F. M. H., Napp, J., Stewart, E. F. (1985). Vertical structure of nearshore plankton off southern California: a storm and a larval fish food web. Fish. Bull. U. S. 83: 151-167

Øiestad, V (1982). Application of enclosures to studies on the early life history of fishes. In: Grice, G. D., Reeve, M. R. (eds.) Marine mesocosms. Springer-Verlag, Berlin, p. $49-62$

Owen, R. W. (1981). Microscale plankton patchiness in the larval anchovy environment. Rapp. P.-v. Réun. Cons. int. Explor. Mer 178: 364-368

Peterson, W. T., Asubel, S. J. (1984). Diets and selective feeding by larvae of Atlantic mackerel Scomber scombrus on zooplankton. Mar. Ecol. Prog. Ser 17:65-75

Reid, F. M. H., Stewart, E., Eppley, R. W., Goodman, D. (1978). 
Spatial distribution of phytoplankton species in chlorophyll maximum layers off southern California. Limnol. Oceanogr 23: 219-226

Shepherd, J. G., Cushing, D. H. (1980). A mechanism for density dependent survival of larval fish as the basis of a stock-recruitment relationship. J. Cons. int. Explor. Mer 39: $160-167$

Silver, M. W., Shanks, A. L., Trent, J. D. (1978). Marine snow: microplankton habitat and source of small-scale patchiness in pelagic populations. Science 201: 371-373

Smith, P. E. (1985). Year-class strength and survival of 0-group clupeoids. Can. J. Fish. Aquat. Sci. 42 (Suppl. 1): 69-82

Stavn, R. H. (1971). The horizontal-vertical distribution hypothesis. Langmuir circulation and Daphnia distributions. Limnol. Oceanogr. 16: 453-466
Underwood, A. J. (1981). Techniques of analysis of variance in experimental marine biology and ecology. Oceanogr. mar Biol. A. Rev. 19: 513-605

Williams, R., Conway, D. V R. (1980). Vertical distribution of Calanus finmarchicus and Calanus helgolandicus. Mar. Biol. 60: $57-61$

Winer, B. J. (1971). Statistical principles in experimental design. McGraw-Hill Kogakusha, Tokyo

Wooldridge, T., Erasmus, T. (1980). Utilization of tidal currents by estuarine zooplankton. Estuar. coast. mar. Sci. 11. $107-114$

Wyatt, T (1972). Some effects of food density on the growth and behavior of plaice larvae. Mar. Biol. 14: 210-216

This article was submitted to the editor; it was accepted for printing on January 15,1988 